\title{
The Effect Of Web Blog Instruction On The Writing Competence Of The English Literature Students, Cultural Science Faculty, Halu Oleo University
}

\author{
Mariani ${ }^{1}$, Wahyudyah Setiyorini ${ }^{2}$, Ela Martisa ${ }^{3}$ \\ Halu Oleo University, (2) Junior High School Of 22 Southern Sulawesi, (3) Halu Oleo \\ University $^{1}$ \\ \{mariani.halim89@gmail.com¹,uho@gmail.com²
}

\begin{abstract}
This research aims to investigate the effect utilizing web blog as a teaching media on students' writing competence. Thirty-one fourth semester students of English Literature study program in the Cultural Science Faculty, Halu Oleo University who took Creative Writing subject in the academic year 2015/2016 participated in the research. Data were obtained from students' results of pre- and post-test, as well as pre-post in-depth interview which was conducted to find out students' perception towards the use of web blogs in their learning. The research analyzed both quantitative data. Two research questions were posed: (1) Is there any significant effect of utilizing web blog on the students' competence in writing? (2) How do students' perceptions of using web blog influence their experiences in their English writing? The researcher runs a paired sample t-test with 2 tailed t-test using the SPSS 16 to test proposed hypothesis. To reveal students' perception, descriptive data were transformed into words. Analysis of the data obtained resulted in the followings: pre-test score $(\mathrm{M}=76.38$; $\mathrm{SD}=8.77)$, post-test score $(\mathrm{M}=86.29 ; \mathrm{SD}=7.78), \mathrm{Df}=30$, $\mathrm{t}$-tabel $=1,697$ and $\mathrm{t}$ test $=10.686$. These results indicated a significant different on students' writing competence before and after treatment. It can therefore be concluded that utilizing web blog as media for teaching writing is effective not only in improving student's writing competence, but also in creating positive learning environment.
\end{abstract}

Keywords: Feedback; in-Depth Interview; Pre-Post-test; Writing Competence; Web Blog.

\section{Introduction}

Writing is extremely a principal point in language skill. It is an activity that will make an attempt to convey and think the sentences and to join them, becoming cohesive and more communicative. Writing is an essential aspect in learning EFL, it is because could enhance grammatical structure, vocabulary and idioms. English spelling, word order, or grammar tenses always can be include among the most frequently appear problems. However, writing is 
not only a language skill that have to be learned in English such as reading, speaking, and listening skills also very important in learning English.

Writing requires more attention to be applied with reason that not only how organize ideas in making an understandable text, but also there are other significant aspect that will be considered such as content, vocabulary, language use, organization, and mechanics. It seems like most of the students says that in English, one of the difficult skills is writing since writing especially in English as a Foreign Language not familiar them. Many of the students in English department need more time to graduate their education only because of their mark of English writing subject does not fulfill the requirement in the passing grade score.

The other major causes why students struggle with writing are because they are unable, for one reason or another, to link into their own knowledge resources in a manner that it could understand by others. Most struggling, students are constrained by their unawareness that others may not understand the information they present through their writing. Students often are unable to expand upon a topic because they do not have a basic understanding that writing is how to communicate the writer's ideas.

Therefore, it can be something that is easy or enjoyable, if there is a good technique, the well method or media that support the teacher in conducting the subject. That is why the researcher here makes efforts to find the solution of those problems, for an example introducing new approaches or techniques and technology as a media in teaching writing to the students.

Giving the students chance to use web blog as a media for writing may be change their perspective and their attitude toward language and it might help them to enhance their coherent composition and technique in writing. The use blog in teaching writing goes to hook within social constructivism theory; this is Vygotsky's theory and it is paradigm of the current educational of instruction to construction and transmission of knowledge. In constructivist approach learning not only assimilates the knowledge transmitted by textbooks and instructors but personally builds and communicates knowledge. As blog in language learning need collaboration, interaction and learning is a mental process of knowledge building (Vygotsky: 1978). Constructivists interpret learning to be more compatible with the current experience as an alteration of experiential memory. In this research, constructivist perspectives are beneficial in online teaching study through discussion. Utilizing Web Blog on EFL Students' Writing Competence is very attractive.

In language learning web blogs have been used experimentally as tools to improve comprehension skills in writing and reading: implications suggest that while web blogs do not substitute face-to-face contact, they should offer a realistic atmosphere where students can focus and construct vocabulary slowly for a real-life audience. (Pinkman, 2005). Web blog have been emerging as a new space to communicate via the internet as online communication. If communication is representing of an intermediate space between speech and writing, blog is classified as occupying an intermediate space between online media. Blog is therefore an especially efficient method for integrating the publication and discussion of students writing in a single format (Mark, 2010).

Web blog is one of technological tools that can help enhance writing quality. In enhancing quality, an individual need practice and feedback Parker \& Chao (2007). In their classrooms, a variety of educators have used blogs and have written about how blogging is based on modern learning philosophy, theory of writing, and pedagogy (e.g., process, post-process, and genre). Positive hopes for using blogs as a New technologies in language education were expressed from an early age. 
Furthermore, Minocha defines blog as a web-based blogging tool consists of a number of articles on a customized web page by the author(s), with posts normally organized at the top of the page in reverse chronology from the most recent post (Minocha \& Roberts, 2008). Furthermore, Parashar Panday (2007) argues that blogs provide students with many advantages as they assist to develop the skills of communicating, posting, reviewing, reflecting, reading, publishing, record keeping, and encouraging communication between individuals and peers. Blogging is also a practice of reading/listening, commenting on thoughts, feelings, experiences, reflecting on thoughts, opinions, experiences, evaluating, asking, denouncing, responding to agreement/disagreement, writing and capturing your reflection, expressing your reflection. In self-reflection, the blog played a favorable role (Miyazoe, 2009)

\section{Method}

This research was quantitative research. Quantitative research aims to collect numerical data and analyze statistical data, meaning that in this research quantitative data has aim to know the effectiveness of using blog in enhance students' writing competence by applying pre-post-test design.

An experimental one-group pre-post-test design methodology implemented in this research. One group participant is pre-test on dependent variable and post-test after the treatment is given. This research includes a pre-test, that indicate students' prior knowledge before treatment and a post-test indicated how participants measured after treatment. The results of pre-test and post-test of the writing competence of the students are compared. The following is the research scheme:

Table 1. The One Group Pre-Test-Post-Test Design

\begin{tabular}{lll}
\hline Pre-test & Independent Variable & Pos-test \\
\hline Y1 & $\mathrm{X}$ & Y2 \\
\hline (Ary, Donald. 1979) &
\end{tabular}

Which:

Pre-test (Y1) is aim to know the students' writing competence before treatment. Treatment (X) is using web blogs as media for teaching to write. The treatments gone to students where the instructors teach the class with internet connection classroom in conjunction with webblog teaching and learning method. Post-test (Y2) is aim to know the students' writing competence after giving the treatment under web-blog. In analyzing the data, the researcher applied quantitative and qualitative data analysis. The data of this research is analyzed by using SPSS version 21. The results of the students were derived from pre-test and post-test observations and analyzed using a descriptive statistics (mean score, median, modus, range, standard deviation). The purpose of the inferential statistics was to test the hypothesis. Non-independent t-test or paired/matched t-test is used in current study to compare the means of two variables in one category (Pre-Post) and to provide N-Gain of the writing composition of students in pre-test and post-test. Qualitative data analysis wass used to analyze and describe the data of students' perceptions after interviewing sheet by using descriptive statistics (describe data into words). 


\section{Result and Discussion}

The descriptive analysis of pre-test score shows that the maximum score was 89.00 , while the minimum scores was 53.50. Both scores indicated that the students' scores of pre-tests were distributed into two criteria, namely very good and good to average criteria. Although the scores distribution was divided into two criteria, the majority of students' scores were in good to average criteria. The mean scores of the above result is 76.39 which is categorized as good to average (Jacob, et al 1981).

In other hand on the descriptive analysis of post-test score in terms of the description of Mean, Standard Deviation, Minimum and Maximum score of post-tests; Mean score of the post-test is 86.29 whereas the standard deviation of the score is 7.79 . The maximum score is 99.50 , and the minimum score is 64.50 .

\subsection{The Effect of Utilizing Web Blog on the Students' Competence in Writing}

The pre and post-test result, it presents that there is an improvement of one level of students' writing competence from "fair to poor" to "good to average". Thus, it can be said there is a positive improvement in students' writing on content aspects after the participant have been exposed with an instruction using a complementary learning of web-blog instruction. In assessing students' writing competence in organization aspect, this research evaluates the aspect through extended profile criteria proposed by Jacobs et al (1981). Writing score in organization aspect is improving from "good to average" to "excellent to very good" after being treated with web-blog program. In addition, there is a positive improvement in students' writing on vocabulary aspects after the participant have been exposed with an instruction using a complementary learning of web-blog program. In all seriousness, after applying web-blog program as a media for teaching writing, the result indicated the technique of teaching writing using blog as a media affect the students' language use in writing positively. The mean score of students in mechanics aspect got 4 points categorized as "good to average" writing criteria, it improves slightly into 5 points categorized as "excellent to very good" after being treated.

\subsection{Students' Perception of Utilizing Web Blog in Writing}

Based on in-depth interviews with the English participants learning experiences, the researchers concluded the following points:

1) There is a lack of an English environment outside the classroom. Most of the participants assumed that this is the end of learning after school since there was no English environment

2) Participants tended not to have self-learning ability and relied too much on their lecturers. Some of them had no idea how independent learning could be done. In addition, after attending the lecture for self-learning and their English learning period, they did not know how to make the best use of time.

3) Many participants indicated that they had little time to speak with their teacher. They also said they were unable to obtain timely input.

4) Some of the participants agreed that it was difficult to learn English writing because they thought it was hard to learn. They did not understand methods for language learning.

5) Some of the participants acknowledged that they were not interested in written English and preferred to spend time on other aspects, such as reading and speaking. 
Furthermore, post-in-depth interview elicit deep information related to participants' perceptions towards social networks in EFL learning. Most of the participants typically spend about an hour on the Internet every day. Instead of using a computer, to connect to the internet, they mostly prefer a mobile phone. They said there was no Wi-Fi on learning's room but there is in official room or in computer laboratory access. It was also not enough for all students to use the small number of computers in the laboratory.

\section{Conclusion}

As the result of data analysis, the concludes that the use of web blogs as media in teaching writing has a significant effect at English Literature Study Program in Cultural Sciences Faculty, University of Halu Oleo, in 2015/2016 of academic year, who had taken the subject of creative writing in semester IV. It is indicating that the students gain higher score on posttest than the pre-test. Based on the results, it showed that the writing competence of students before and after the treatment significantly has a difference. The use of blogs as an effective writing learning media to improve students' writing competence and produce a positive learning environment for students.

\section{References}

[1] Ary, D; Jacob, L.C; Razavich, A. 1979. Introduction to Research in Education. US: Holt, Rinchart and Winston.

[2] Brescia.F.J. \& Miller, M.T. (2006). What's it Worth? The Perceived Benefits of Instructional Blogging. Electronic Journal for the Integration of Technology in Education, 5, 44-52, http://ejite.isu.edu/Volume5/Brescia.pdf, last retrieved 28.08.2011

[3] Jacobs H.L, Zirgkgaf, S.A. Wormuth, Dr, Horfiel, V.H, Hughey. (1981). Testing EFL Composition. A Practical approach English CompositionProgram. USA: Newburg House Publisher.inc

[4] Li, Wei. (2015). Hot Blogging: Exploring English Writing Experiences of Undergraduate Students in China. Thesis, University of Calgary. Alberta.

[5] Mark, Warschauer. 2010. Invited Commentary: New Tools for Teaching Writing. Language Learning \& Technology, Vol. 14 No.1, http: llt.msu/vol14num1/commentary.pdf

[6] Minocha, S., \& Roberts, D. (2008). Social, usability, and pedagogical factors influencing students' learning experiences with wikis and blogs. Pragmatic \& Cognition 16:2 (2008), 272-306.

[7] Miyazoe, T., Terry Anderson 2010. Learning Outcomes and Students' Perceptions of Online Writing: Simultaneous Implementation of a Forum, Blog, And Wiki in An EFL Blended Learning Setting. System: An International Journal of Educational Technology and Applied linguistics. Volume 38, Issue 2. June, 2010.1

[8] Pashar Panday, P. (2007). Why Blogs? Retrieved December 12, 2015, from http://net.educause.edU/ir/library/pdf/CSD4902.pdf

[9] Parker, K. R., \& Chao, J. T. (2007). Wiki as a teaching tool. Interdisciplinary Journal of Knowledge and Learning Objects, 3, 57-72. 
[10] Pinkman, K. (2005). Using Blogs in the Foreign Language Classroom: Encouraging Learner Independence. The JALT CALL Journal, 1 (1). Retrieved (9/3/11) from http://www.esljournal.com.

[11] Vygotsky, L., 1978. "Interaction between Learning and Development", pp: 79-91. In Mind: in Society. Cambridge,

[12] Mass: Harvard University Press. 